\title{
Why Did Kuhn's Structure of Scientific Revolutions Cause a Fuss? ${ }^{1}$
}

After the publication of The Structure of Scientific Revolutions, Kuhn was criticised for the apparent relativism of his view. By way of defence, Kuhn presented himself as an historian among philosophers, ${ }^{2}$ with an historian's view of scientific progress. In the postscript to the second edition of Structure he observed that, "Compared with the notion of progress most prevalent among both philosophers of science and laymen" his (Kuhn's) position "lacks an essential element" (1970 p. 206). Kuhn recognised that a successful scientific theory is usually a better instrument for finding and solving puzzles than its predecessor. That is what he meant by 'progress'. The missing element required by philosophers of science (and the laity) is the thought that "successive theories grow ever closer to... the truth". Of this he says,

There is, I think, no theory-independent way to reconstruct phrases like "really

there'; the notion of a match between the ontology of a theory and its "real" counterpart in nature now seems to me illusive in principle. Besides, as a historian, I am impressed with the implausibility of the view. ${ }^{3}$

As an illustration Kuhn goes on to explain that in some ways Einstein seems to him to have had more in common with Aristotle than either of them had with Newton. The difference between Kuhn's conception of progress and the 'truth-approaching' notion insisted on by his critics is, if anything, too well-known. What I wish to focus on is Kuhn's articulation of this contrast as a stand-off between history and philosophy.

A little later in the same postscript he muses on the enthusiasm with which the pattern displayed in Structure has been taken up and brought to bear on problems far outside the history and philosophy of science,

To the extent that the book portrays scientific development as a succession of tradition-bound periods punctuated by non-cumulative breaks, its theses are undoubtedly of wide applicability. But they should be, for they are borrowed from other fields. Historians of literature, of music, of the arts, of political development, and of many other human activities have long described their subjects in the same way. Periodization in terms of revolutionary breaks in style, taste, and institutional structure have been among their standard tools. ${ }^{4}$

In other words, Kuhn attempted to fend off accusations of extremism by explaining that his allegedly 'relativist' theory is little more than the mundane analytical apparatus common to most historians. The appearance of radicalism is due to the novelty of applying this machinery to the history of science.

The trouble with Kuhn's defence ('ain't nobody here but us historians') is that professional historians had written on science before Kuhn. The works of Butterfield and Koyré (to name two of Kuhn's acknowledged precursors) did not cause polemical explosions comparable to the one that greeted the publication of Structure. Yet Kuhn learned his craft from these writers. His historiographic practice was, as we shall see, largely derived from theirs. Moreover, the philosophical community greeted the publication in 1957 of Kuhn's own book on the Copernican revolution with relative equanimity. So the fuss cannot have been generated merely by the application of standard historiographic technique to the history of science.

The claim of this paper is that Kuhn inadvertently allowed features of his procedure and experience as an historian to pass over into his general account of science. For example, consider the infamous Gestalt shift. When he first wrote Structure, Kuhn thought that during a revolution scientists undergo something like the aspect-dawning experience of seeing a picture of a duck turn into a picture of a rabbit ${ }^{5}$. He later retracted this claim, arguing that scientific revolutions are social phenomena that take place over an extended period, whereas 
Gestalt shifts are personal and instantaneous. The autobiographical remarks in the preface to The Essential Tension clarify the source of the error: an historian may experience an instantaneous switch when she thinks her way back into a worldview separated from our own by one or more paradigm-shifts. ${ }^{6}$ Suddenly she finds herself looking through (e.g.) Aristotelian eyes (or, to say exactly the same thing with different grammar, she suddenly finds herself living in an Aristotelian world). It is the historian, not the scientist, who is tempted to declare that (e.g.) 'after Copernicus, astronomers lived in a different world'. For a scientist who lives through it, the two sides of a paradigm-shift are united in the continuity of his experience-which is not to deny that (e.g.) Aristotelian and Galilean physicists experienced the relevant aspects of the world differently. The dissociation of the past into sharply distinct 'worlds' is a moment in the historian's experience only. ${ }^{7}$

In this case, Kuhn projected an element of his experience as an historian (i.e. the Gestalt shift) into his account of the development of science, saw his error, and withdrew it again. The thesis of this paper is that he projected other elements of his historiographic experience and procedure into his model of science, but failed to notice clearly that he had done so. Kuhn's stated aim in Structure is to offer "a sketch of the quite different concept of science that can emerge from the historical record of the research activity itself" (1970 p. 1). The claim of this paper is that Kuhn's concept of science owes as much to the way he looked at the past as it does to what he found there. That is to say, the 'historical record' is an intellectual product. The historians who write it have methodological commitments, and these commitments induce certain gross features in the image of science that results. For a simple example, consider the quotation above about periodisation. For Kuhn, "Periodization in terms of revolutionary breaks in style, taste, and institutional structure" is a "tool". So it is, but using it commits one to a general thesis, namely, that such revolutionary breaks did occur. The polemical storm broke over Structure rather than The Copernican Revolution because it is in Structure that the promotion of historiographic method into philosophical theory took place. It is only in Structure that the hitherto implicit methodological commitments of Kuhn and his mentors condensed into a general model of science that English-speaking philosophers could recognise and with which they could take issue. However, let no one suppose that this is intended as a complete reading of Structure. Kuhn's philosophy of science includes much that cannot be traced to his historiographic practice-such as his account of the formation of concepts or his Orwellian view of scientific education. Nevertheless, I contend that this reading can explain much of the heat and confusion caused by Structure.

Obviously, we have to examine the historiographic practice that Kuhn learned from his exemplars before we can recognise it in his model of the scientific process. First though, we need to understand Kuhn's sense of his position as an historian among philosophers. In particular, we must establish that he was sufficiently naïve about his own practice to allow the transformation of historiographic method into philosophical model to take place largely unnoticed. For it is part of the present argument that, though Kuhn insisted that history has dramatic implications for the philosophy of science, he never set out the relation between these disciplines with sufficient clarity to explain how those implications are drawn.

\section{European Historian, American Philosopher}

Kuhn, in spite of his protestations, was not simply an historian. Rather, his intellectual personality was split. Many of his heroes wrote history with overt philosophical intent (e.g. Brunschvicg, Meyerson, Dijksterhuis and Koyré). Indeed, Kuhn had to be philosopher enough to seek a general model of scientific change for the encounter between the two disciplines to take place. Nevertheless, he claimed that the hostile accusations of relativism and irrationalism arose because he was writing as a historian, whereas his noisier 
critics were reading as philosophers. Discussing the reception of his incommensurability thesis, he declared that, "Only philosophers have seriously misconstrued the intent of these parts of my argument" (1970 p. 198; emphasis added). Kuhn did not attempt to specify exactly what it is about philosophy that caused its practitioners to misread him.

We know what 'philosopher' meant to Kuhn in this context. Philosophy of science in North America, in the decades surrounding the Second World War, was 'positivist' (speaking loosely and with apologies). That is to say, formal logic was the principal tool, antipsychologism was the received wisdom and the tension between empiricism and realism was the central problem (in this loose sense most critical rationalists were also 'positivists'). His understanding of 'historian' is more elusive. Kuhn explored the contrast between the history and the philosophy of science in the initial chapter of The Essential Tension. However, he was unable to throw much light on the problem, partly because he was largely self-taught as a historian but mostly because his sparse philosophical education was in the Anglophone tradition. This (as Kuhn tells it) prevented him from grasping the intellectual background of the historical tradition in which he found himself:

The early models of the sort of history that has so influenced me and my historical colleagues is the product of a post-Kantian European tradition which I and my philosophical colleagues continue to find opaque. ${ }^{8}$

This confession does not seem to be false modesty. The chapter in The Essential Tension entitled 'The History and the Philosophy of Science' observes that history seeks to understand particulars in their contexts whereas philosophy looks for the universal aspect of any given particular. The article next records the practical consequences of these differing goals for the graduate students in Kuhn's seminar; and it fulminates against the covering-law model of historical explanation before concluding that the two disciplines should seek co-operation rather than union. The banality of these ruminations suggests that the "post-Kantian European tradition' really was a closed book to him. Nevertheless, in rejecting the covering-law model of historical explanation Kuhn effectively abandoned the only philosophical tradition to which he had ready access. And he knew it,

I suspect that anyone who believes that history may have deep philosophical import will have to learn to bridge the longstanding divide between the

Continental and English-language philosophical traditions. ${ }^{9}$

Kuhn, of course, did believe that history has 'deep philosophical import'. ${ }^{10}$ Since he never bridged the continental/anglophone division, it follows (on his own account of the matter) that he did not fully understand the logic of his own work.

As this last quotation indicates, the real division between Kuhn and his philosophical critics is not quite that between history and philosophy. ${ }^{11}$ It is, rather, between Kuhn's heroes-historians and historian-philosophers such as Butterfield, Lovejoy, Brunschvicg, Meyerson, Dijksterhuis, Maier and above all Koyré ${ }^{12}$ — and his colleagues in the anglophone (loosely speaking 'positivist') philosophy of science tradition ${ }^{13}$. The European philosophers among Kuhn's mentors belong with the historians rather than with the English-speaking philosophers because the contrast is not with history but with historicism. The philosophers in Kuhn's pantheon belong to a period in European (particularly French) thought that was, as Koyré put it,

So infected with historicism that it does not realise that it could have any selfknowledge except historical self-knowledge, a period that does not admit that it could understand and explain itself to itself except through and as a function of its past, its history. ${ }^{14}$

This was not true of the English-speaking philosophers of science who took Kuhn to task for his relativism. Their training tended to be in mathematical logic and natural science rather 
than in the historical humanities. The contrast then, is not simply between history and philosophy (it cannot have been, because Kuhn was a bit of both). It was between historians and historicist philosophers on the one hand, and philosophers whose intellectual habits were formed by the mathematical and natural sciences on the other. What, then is historicism?

\section{Herbert Butterfield}

In the generation before Kuhn's own, Herbert Butterfield attacked the characteristic grand narrative of the British establishment in The Whig Interpretation of History. This 'Whig interpretation' reads British history as a tale of inevitable progress towards our present happy state of protestant freedom. Butterfield's attack on this story was sufficiently general to take in any progressivist historiography - the history of science not excepted. By Butterfield's time the nineteenth-century turn away from treating the past as preparation for the present was well entrenched. First the history of philosophy and then (beginning in the 1920s) the history of science had received this revolution. ${ }^{15}$ This 'historicism' begins with a determination to treat the past 'in its own terms' rather than in terms drawn from the present or from some other extraneous source. By 1931 this 'historicist' movement was sufficiently well defined for Butterfield to summarise its argument in a short book-The Whig Interpretation. Butterfield is a happy case for the present purpose, because he also wrote on the history of science (and contributed to the anthology in celebration of Koyré's seventieth birthday ${ }^{16}$ ). Kuhn cited Butterfield's The Origins of Modern Science as an influence on his own study of the Copernican revolution and saw in Butterfield a fellow admirer of Koyré. Indeed, he credited Butterfield with having popularised Koyré's ideas in the English-speaking world. In particular he pointed to Butterfield's thesis that the upheaval in early modern European science did not result from new or more accurate observations but rather from a "transposition in the mind", "a different kind of thinking-cap". ${ }^{17}$ In this Kuhn found an intimation of his own view that a scientific revolution involves a change in the scientific Gestalt.

In The Whig Interpretation of History Butterfield argued that partisan history-including 'whiggish' (that is, progressivist) history-need not result from a bias in the treatment of sources. Rather, the danger comes when the research papers and monographs of specialist scholars are abridged and combined to form a single synoptic treatment. "Abridgements may be based more or less consciously on some selective principle..." Butterfield's alternative is not a random culling of details, but rather a synopsis which does not "change the meaning and purport of the historical story in the mere act of abridging it." This is possible, according to Butterfield, if the abridgement is "the condensation of a full mind". Rigour consists in awareness of and fidelity to the details revealed in the specialist research, because history is "the whole network produced by countless complications perpetually involving each other" (1931 pp. 74-75). Abridgement is the problem of how to "reduce details without losing the purport and tenor of the whole" (op. cit. p. 76).

Kuhn's own account of historical explanation is brief, but it bears fruitful comparison with that of Butterfield:

The final product of most historical research is a narrative, a story, about particulars of the past. In part it is a description of what occurred (philosophers and scientists often say, a mere description). Its success, however, depends not only on accuracy but also on structure. The historical narrative must render plausible and comprehensible the events it describes. ${ }^{18}$

Notice that 'philosophers' is used here in the special sense discussed above. The historian's explanatory effort is constrained by appropriate standards of rigour. For example, the characters appearing in the story should be plausible human beings. There should not, for example, be too many road-to-Damascus conversions in one lifetime. Of most significance for our purpose is 
the requirement that, "There may be no empty spaces in the middle... of the narrative. Nor may there be any discontinuities." "In other words, a Kuhnian historian takes it for granted that the past has no gaps, and tries to reflect this unity in his writing. Let us call this the diachronic unity principle. He continues:

If history is explanatory, that is not because its narratives are covered by general laws. Rather it is because the reader who says 'Now I know what happened,' is simultaneously saying, 'Now it makes sense; now I understand; what was for me previously a mere list of facts has fallen into a recognizable pattern. $^{20}$

These views on the nature of historical understanding do not collapse into one another. Kuhn seeks recognisable patterns in the mass of facts, while Butterfield hopes to discern the purport and tenor of the totality. These formulations are not equivalent. Patterns are more portable than import and tenor. We may intelligibly hope to find the same pattern exhibited in several distinct contexts (indeed this is the claim of Structure), whereas the purport and tenor of a narrative is, presumably, unique. Nevertheless, there is a clear affinity, especially in contrast to the covering-law theory. The problem of abridgement was serious for Butterfield because his history of science, like that of Koyré, spanned centuries. Histories of this sort require periodisation, which in turn raises the problem of the transition from one period to the next. Thus in the content, form and method of Butterfield's history (including his history of science) we find intimations of some of the themes that would bulk large in Structure.

The Whig Interpretation of History also prefigures Kuhn's views concerning the relation between history and philosophy. Butterfield's ideal historian "is concerned with the concrete and is at home in the world of facts and people and happenings" (p. 52). For example,

[The historian] explains the French Revolution by discovering exactly what it was that occurred; and if at any point we need further elucidation all that he can do is to take us into greater detail, and make us see in still more definite concreteness what really did take place. ${ }^{21}$

Consequently, Butterfield's historian carries us "away from the world of general ideas" (p. 56). In this his instinct is opposed to that of the philosopher who seeks universal conceptual order in the teeming motes of detail that make up concrete life. A philosophically-minded historian tends to become bored with "the waste and triviality and repetitiveness of all the things it is his business to notice" (pp. 52-53) and is tempted to impose upon this irrelevant mass the general notions which are his real concern. ${ }^{22}$ Whiggish history commits this sin by taking present-day ideas and treating them as general notions in this sense. Covering-laws also sin against the historicist care for the specificity of concrete historical detail, since in order to apply a law we must first abstract the event in question from its proper context.

Since we are seeking the source of Kuhn's alleged relativism, it is well to note that for Butterfield, "it is not the role of the historian to come to what might be called judgements of value" (p. 57). This ethical neutrality is not the even-handedness expected of umpires and magistrates. Rather, it arises from the fact that in order to pronounce an ethical judgment on this deed or that character it is necessary to abstract the object from the flux in which it figures and to consider it as an instance of a type (what do we think of people who foment revolutions?) or at the very least to subject it to anachronistic comparisons (how do the French and Russian revolutions compare?). The historian fulfils his role when he,

Takes us away from simple and absolute judgments and by returning to the historical context tangles everything up again. He is back in his proper place when he tells us that a thing is good or harmful according to circumstances, according to the interactions that are produced. If history can do anything it is to remind us of those complications that undermine our certainties, and to show us 
that all our judgements are merely relative to time and space. ${ }^{23}$

Thus, relativism is natural to historicists like Butterfield for whom historical explanation is a matter of embedding the explanandum in its proper context. To judge is to decontextualise and that, on his view, is unhistorical.

No-one now supposes that Butterfield gave a plausible description of historiographic practice. ${ }^{24}$ His negative polemic against 'whiggish' history is on the whole judged to be successful, but his positive account has a methodological hole. He never explained how immersion in the details of the evidence enables a historian to grasp the 'tenor and purport' of the whole. The same point arises when we consider the historian's readership. An historian has to make the past intelligible to present-day readers, and this cannot be achieved simply by piling up facts - especially if these facts are couched in an antique vocabulary. Having grasped an episode 'in its own terms' (that is, taking account of contemporary concepts, institutions, idioms and so forth), an historian must then translate this understanding for the benefit of present-day readers. Butterfield is long on the historian's duty to the past but very short on her responsibilities to her readership. Koyré, as we shall see, was acutely aware that to give a reading of an antique text is to translate it (see below for his remarks on reading Euclid, for example). In this respect Koyré's historicism is subtler than that of Butterfield. While Butterfield argued that successes and failures, and virtue and wickedness, are relative to their historical times, Koyré showed that our understanding of the past is relative to the present. For the current purpose these shortcomings do not matter (though it may be significant that Kuhn shared them to some extent- on page one of Structure he writes of 'the historical record' as if the evidence had somehow assembled itself spontaneously). The success of Butterfield's polemic against whiggish history indicates that he had accurately articulated the historicist mood of historians between the wars. Let us turn then to the common inspiration for Butterfield and Kuhn.

\section{Alexandre Koyré}

"More than any other single scholar" wrote Kuhn, "Koyré was responsible for... the historiographical revolution" by which whiggish history of science was overcome. ${ }^{25}$ Koyré earned this praise by his approach to the original texts. For whiggish historians of science (as Kuhn tells it) the point of reading the originals was to pinpoint the moment when some part of present-day scientific method or doctrine was discovered. Hence the major works could be read quite quickly, possibly in translation, and the surrounding literature not at all. Koyré, by contrast, was determined to set his historical scientists in their proper times. This required him to read the surrounding texts ${ }^{26}$, including works by the subject's predecessors, contemporaries and immediate successors - in the original languages (Koyré read French, Russian, German, English, Dutch, Italian, Latin (medieval and renaissance) and mittelhochdeutsch ${ }^{27}$ ). The reward for this labour was a far more plausible history. In Kuhn's words,

His Galileo (or Copernicus, or Newton) is no longer a modern scientist struggling to transcend the errors of his predecessors and the superstitions of his times. Nor is his Galileo even a man travelling a route which leads straight to Newton. Instead he is... an Italian of the Counter-Reformation, at once a more plausible, and more fascinating figure. ${ }^{28}$

The Newton who wrote on optics is the same man who wrote on alchemy. This fact becomes mysterious if we write up the first figure as a modern scientist out of time (since such a person would never write seriously about alchemy). Thus, paying attention to the surrounding texts makes whiggish history all but impossible.

Kuhn's assessment is correct so far as it goes. For example, Koyré insisted that Euclid should be read with a commentary that would distinguish Euclidean thought from modern 
thinking and would make explicit the 'mental structure' upon which Euclid's edifice stands. Otherwise, Euclid's geometry may seem like modern mathematics done badly in a clumsy notation. ${ }^{29}$ However, there was more to Koyré than an indefatigable care for inter-textual analysis. Koyré was a student at Göttingen from 1909 until 1914 (with some interruptions) and there encountered the phenomenologists Edmund Husserl and Adolf Reinach. Koyré was never an uncritical follower of Husserl. We do not find in his work the technical apparatus of Husserl's system and (like most of Husserl's students) he did not accept Husserl's 'transcendental idealism'. ${ }^{30}$ However, in a letter of 1953 to Herbert Spiegelberg, Koyré wrote, Now your question, how far I am still a phenomenologist-I don't know myself.

I have been deeply influenced by Husserl, probably learned from him-who didn't know much about history-the positive approach to it; the interest for the objectivism of Greek and medieval thought, for the intuitive contents of seemingly purely conceptual dialectics... ${ }^{31}$

By 'objectivism' here Koyré seems to have meant to say that terms such as 'Greek thought' or 'medieval thought' are informative because they refer to some objective historical category. ${ }^{32}$ 'The intuitive contents of seemingly purely conceptual dialectics' refers to the experiential side of scientific life (remembering the semi-technical sense of 'intuitive' in phenomenology). To be (e.g.) a Ptolemaïc astronomer is to be struck by the night sky in a certain manner, as well as to master the relevant doctrines and mathematical techniques. This is the very point that Kuhn later made with the aid of the psychology of perception: to belong to a particular school of scientific thought is, among other things, to be locked into its Gestalt. ${ }^{33}$

Koyré turned Husserl's phenomenology into a historiographic method in the following way. Each human being defines an intentional world. The general framework of such a world is a system of ideas. 'Idea' is to be read here in a quasi-Platonic fashion, though as just remarked, these systems have their 'intuitive contents' too. The task of the historian of science or philosophy is to reconstruct in her own thought the relevant part of the intentional world of the historical scientist or philosopher in question. Koyré found a new use for the phenomenological device of 'bracketing' (leaving to one side) all questions about the accuracy of the intentional world as a representation of the 'real' (Selbstverständliche) world. ${ }^{34}$ 'Bracketing' allows a historian to concentrate on the dialectical evolution of the succession of intentional worlds. This conception of the historian's task recalls Collingwood's 're-enactment' model, ${ }^{35}$ except that Koyré was more inclined to grant ideas an objective existence of their own. ${ }^{36}$ Now, a Husserlian intentional world is not the same as a Kuhnian disciplinary matrix. Each human being defines a separate intentional world, whereas a disciplinary matrix is a public, inter-subjective item. Koyré bridges this gap. Where Husserl principally studied the structure of individual consciousness ${ }^{37}$, Koyre sought the 'framework' or 'structure of thought' common to a scientific or scholarly community at a given time. ${ }^{38}$ Thus we have here a plausible ancestor for Kuhn's conception of a disciplinary matrix: a partly-private partly-social complex of thought and sensibility that may be compared with others of its kind only with difficulty, and cannot be compared with 'real' reality (if such a thing exists) at all. Göttingen phenomenology may be the major part of the 'post-Kantian European' philosophical tradition that stumped Kuhn and his philosophical colleagues. ${ }^{39}$

In this paper we are concerned with historiographic method, but for completeness we can note some debts at the level of content. Koyré argued, before Kuhn and Butterfield, that the Scientific Revolution was not brought about by better observations, but by conceptual changes, by (as Butterfield put it) the emergence of a new and specifically mathematical kind of thinkingcap. ${ }^{40}$ In this sense Koyré was the intellectualist heir of Descartes while Kuhn's anglophone philosopher colleagues tended to a more Baconian view. One of the struggles happening in and after Structure was a modern version of that antique dispute. ${ }^{41}$ Koyré was also committed to the 
historical unity of thought. Science, philosophy and theology interpenetrate, and the development of one cannot be understood without reference to the other two. For example, Koyré maintained that Galileo freed himself from Aristotle in part by rediscovering Plato. ${ }^{42}$ In general, 'a new thinking-cap' will affect one's philosophy (and perhaps religion) as well as one's science. In particular, a scientific revolution will require a change in metaphysics. ${ }^{43}$ This is a familiar point of difference between Kuhn and his philosopher colleagues, who tended to insist on the autonomy of science from other disciplines and enterprises. Note that we have here another appeal to unity (to go with the diachronic unity principle): the unity of thought. ${ }^{44}$

To turn now to the question of evaluation: Koyré had no extra-historical standard of scientific rationality. On the contrary, for him reason itself develops historically (he cited Brunschvicg's Étapes de la philosophie mathématique as the source of this insight ${ }^{45}$ ). Moreover, his historical characters are all reasonable people. When they deviate from our present-day norms, they do so for what are, in context, good reasons. Indeed, it is inevitable, given the hermeneutic method that he shared with Kuhn, that it should be so. An appearance of irrationality or uncharacteristic stupidity on the part of a significant historical character shows that we have not understood him yet. Kuhn employed the same criterion:

When dealing with subjects other than physics, Aristotle had been an acute and naturalistic observer... How could his characteristic talents have failed him so when applied to motion? And... why had his views been taken so seriously for so long a time by so many of his successors?... One memorable (and very hot) summer day those perplexities suddenly vanished... I did not become an Aristotelian physicist as a result, but I had to some extent learned to think like one. $^{46}$

The answer, in this case, was that 'motion' in Aristotle included other kinds of change than displacement. Since the reasonableness of historical characters is a necessary criterion of having successfully understood their writing, there can be no extra-historical standard of rationality in this historiography. A non-trivial standard would find some historical figures irrational-but for Koyré and Kuhn this would show that the historian's work was not yet done. For them, it is a methodological principle that famous authors who seem irrational are merely misunderstood. ${ }^{47}$

Koyré did believe that science makes progress. This comes out when he makes the case for studying discarded and disproved theories. The nature of science shows itself precisely in its efforts to overcome error:

Science does not stride from definitely established truths to other definite discoveries. Science is progress, advancement towards truth; its value is in its dynamism which lets nothing remain still and in place; and only the study of this effort of human thought in its struggle for knowledge of reality can reveal to us the sense of its dynamism, the sense of the fundamental notions it employs; and the image of the past will help us to define suitable norms for the future. ${ }^{48}$

Science, for Koyré, is the journey (acheminement) towards truth rather than the possession of truths. This journey is not guided by an ahistorical scientific method, nor is the route predetermined. It can be reconstructed as progress, but only retrospectively. Koyré seemed to think that it is necessarily an endless journey. In any event, the primary object of study for Koyré is a succession of intentional worlds. 'Real', unmediated reality never enters the historian's field of enquiry. It cannot, for the historian's task is to reconstruct past thought. 'Nature' only enters insofar as historical characters think about it. Consequently Koyré's conception of history, like that of Kuhn, prevents him from arguing that "successive theories grow ever closer to... the truth"- - even if he happened to think that they do. ${ }^{49}$ 


\section{Against Prophecy}

In the final chapter of Structure Kuhn used a biological analogy to explain his conception of scientific progress. Before Darwin (Kuhn explains, 1970 pp. 171-2) evolution was thought (whiggishly) to be directed towards the emergence of humans, either by God or by some less personal providence. New with Darwinism was the idea that the differentiation of species is not aimed at any goal. So it is with Kuhn's conception of scientific progress. We are used to the thought that the march of science advances towards something called 'the truth'. "But" asks Kuhn rhetorically, "need there be any such goal? Can we not account for both science's existence and its success in terms of evolution from the community's state of knowledge at any given time?" (1970 p. 171; emphasis added). Even if there were a Truth, a Reality waiting 'out there' to be discovered, historians can have no use for it because historians, like evolutionary biologists, explain by pointing backwards, not forwards. To do otherwise would be to slip into prophecy, and for Kuhn, "An ability to predict the future is no part of the historian's arsenal. He is neither a social scientist nor a seer." confesses, his lack of a philosophy of history prevents him from explaining exactly why prediction is not part of the historian's job.

Butterfield and Koyré can give us some reasons why historians cannot prophesy. For Butterfield, to treat the past as preparation for some future consummation is to make the same error as the Whig, who treats it as preparation for the present. In either case some general scheme, some grand framework must be forced upon the details of the past, and will inevitably distort our view of them. For Butterfield, the historian explains by fitting a mass of detail together. Events in the future cannot be treated this way because the surrounding details are not yet available to us. Therefore, prophecy requires an appeal to some explanatory factor that does not draw its meaning from its context and circumstances. But (for Butterfield) there is no such thing:

There is not an essence of history that can be got by evaporating the human and the personal factors, the incidental or momentary or local things, and the circumstantial elements, as though at the bottom of the well there were something absolute, some truth independent of time and circumstance. ${ }^{51}$

Appeals to such essences as 'human nature' or 'the scientific method' violate the historian's methodological commitment that everything is in flux. Whenever some apparently universal essence is proposed, Butterfield's historian will ask: how and when did it originate? How did it develop? And (if appropriate) what caused it to pass out of existence? Once thus historicised, our allegedly ahistorical principle can no longer serve as a guide to the future since we do not yet know how the future will treat it. We do not know what relations it will have with its future circumstances.

As we saw above, Koyré allowed that lessons may be drawn from history. However, general maxims are not predictions. Furthermore, the history of science is marked by revolutionary changes (revolutionary in the sense that they included the overthrow of entire bodies of metaphysical and methodological orthodoxy). The outcomes of these could not have been predicted, and there is no reason to think that there will be no more such revolutions in the future. Further, Koyré's historicism shows itself in his rejection of Meyerson's account of scientific rationality. For Meyerson, reason is, always and everywhere, a search for identity. We need not now ask exactly what Meyerson meant by this. The point is that for Koyré, the historian's task is to understand change. ${ }^{52}$ This work starts by noticing differences-in this case between the characteristic intellectual habits and tempers of distinct historical periods. If, following Meyerson, we insist that human thought is always fundamentally the same, then the historical task of explaining its development cannot even begin. ${ }^{53}$ Meyerson offers the principle 
of identity as the ahistorical essence of reason, apparently 'independent of time and circumstance'. Koyré, following Brunschvicg, shows the historical variation of this apparently changeless essence. Like Butterfield, Koyré regards an apparently ahistorical element that always and everywhere acts the same way as a sign that the historian has more work to do. An allegedly atemporal principle is, for these historians, simply waiting for historical treatment, at the end of which its genesis and development will appear as an inseparable part of the greater historical flux.

In the programmatic remarks at the beginning of Structure, Kuhn seeks to forestall the objection that historical study cannot in principle affect our view of the logic of science. "An entire arsenal of dichotomies is available to suggest that it cannot properly do so" (p. 8). History is said to be descriptive and interpretative, whereas logic is normative. Kuhn (it is said) mixes up history and epistemology, but fastidious philosophers of science keep them apart with the aid of the distinction between the context of discovery and the context of justification. Kuhn's argument against these famous dichotomies is that whenever he tried to employ them they just got in the way:

My attempts to apply [these distinctions] even grosso modo, to the actual situations in which knowledge is gained, accepted, and assimilated have made them seem extraordinarily problematic. Rather than being elementary logical or methodological distinctions, which would then be prior to the analysis of scientific knowledge, they now seem to be integral parts of a traditional set of substantive answers to the very questions upon which they have been deployed. $^{54}$

In other words, the philosophical dichotomies ceased to be part of the answer and became part of the question. This is exactly what we would expect. A historian in Koyré's or Butterfield's mould would show that these dichotomies have histories during which they became (for philosophers of a certain place and time) 'elementary logical or methodological distinctions'. Kuhn did not do this explicitly, but that is how one would support his claim. 'Elementary logical or methodological distinctions' are presumably timeless, but 'a traditional set of substantive answers' implies a historical process in which the tradition mentioned emerged and became an orthodoxy. Kuhn, like Butterfield and Koyré, cannot prophesy because this requires the deployment of some principle that acts on the historical process without participating in it. This is the connection with social science (recall the quotation in which Kuhn contrasts social scientists, who do make predictions, with historians, who do not). Social scientists (in Kuhn's imagination at any rate) seek universal laws: "What has troubled me about the covering law model is that it makes of the historian a social scientist manque." "55 This is troubling because universal laws, or universal anything else, are methodological anathema to an historicist historian. ${ }^{56}$

\section{Another Unity Principle}

For Butterfield, Koyré and Kuhn, a sound historical explanation is one in which the various elements are all part of the same historical flux. Let us call this the principle of metaphysical unity. The traditional philosophical approach sins against this principle in two ways. First, it requires the distinctions just mentioned (logic/psychology, discovery/justification, etc.) to be treated ahistorically as timeless logical truths. This, as we have seen, is methodologically impossible-everything is to be treated historically. Second, they require that some historical phenomena be understood logically while others are to be explained by sociology or psychology. This divides the flux of history in two absolutely separate parts.

It might be objected that Kuhn simply replaces the traditional distinctions with new ones 
of his own. One might cite, for example, his distinction between immature and mature disciplines; or between normal and revolutionary science. However, these Kuhnian distinctions do not mark out phenomena for differing kinds of explanation. Mature and immature disciplines only differ by degree and are subject to the same kind of historiographic scrutiny. Similarly, though Kuhn finds deep differences between normal and revolutionary periods of science, he approaches these differing phases with the same intellectual tools in hand. To divide the history of science into contexts of discovery and justification is to violate this metaphysical unity principle. Ultimately, historical phenomena explain each other by cohering into a single account. To partition phenomena into mutually independent categories is drastically to reduce the range of inter-phenomenal relations available to the historian. If we do respect the standard philosophical distinctions, then a description of events in (e.g.) the context of discovery cannot cohere with, nor can it fail to cohere with, a description of related events judged to belong to the context of justification. Thus explanatory resources are denied to the historian and critical resources are denied to her colleagues. ${ }^{57}$

\section{Conclusion}

The thesis of this paper is that Kuhn worked into his model of science the historicism found in Koyré and Butterfield. This historicism has the following features:

1. The past is a single flux, the parts of which mutually explain each other.

Narratives should not have gaps or arbitrary changes of direction. The past must not be partitioned by ahistorical dichotomies (rational/irrational, scientific/non-scientific, etc.). Cause and effect, explanans and explanandum are all to co-exist on the same metaphysical level. Attempts to separate objective scientific argument from human frailty violate this principle. We can and must draw distinctions in history, but elements distinguished may still be significantly related. Any apparently changeless element is to be treated historically, i.e. its genesis and development revealed.

This is part of the point of the distinction between theories and disciplinary matrices. A disciplinary matrix is scientific thought embedded in its historical context, while a theory is that same thought abstracted. Other manifestations of this feature in Kuhn are his refusal to partition the past with philosophical dichotomies; his commitments to (what are here called) the diachronic and metaphysical unity principles; and his refusal to recognise any standard higher than the assent of the scientific community in question.

2. The historical significance of an event depends solely on its relations with the rest of the flux.

Any covering-law or ahistorical essence that we might invoke to explain some event would violate point 1 . Nevertheless, the past is not just a blooming, buzzing confusion because events and historical phenomena are related to each other. These relations make the whole intelligible.

We saw above that Kuhn commits himself to this explicitly (his historians write "a description of what occurred (philosophers and scientists often say, a mere description)."). It may also manifest itself in his meaning-holism.

\section{Historians explain by looking back.}

To write history as eschatology, as progress towards some final state (be it a complete natural 
science or the Kingdom of God) is to violate the rule that causes precede their effects, and also point 2. Again, Kuhn's commitment to this point is explicit (he argued it with the Darwinian analogy).

\section{All history is the history of thought.}

That is, to understand an action is to understand the thinking embodied in it. In the history of science, 'the world' enters only as an object of thought for historical characters, and therefore only as they thought it, not as it is in itself. Kuhn says that future knowledge of the Truth cannot explain the direction of past science, since historians do not refer to the future to explain the past. However, this does not explain why the Truth about Nature should not contribute directly to our understanding of an episode in historical science. After all, Nature was, as it were, present at the time. However, this 'idealist' view of history explains why reference to Nature is never direct in Kuhnian history, but always mediated by the science of the time.

5. The history is divided by revolutionary breaks—-but these are neither neat nor absolute.

One kind of thinking-cap may wholly supersede another, but scientists need not all change their hats on the same day. Moreover there will be continuities across these breaks: every revolution is both a break with and an evolution from what went before. In Structure Kuhn rather plays up the ruptures and his critics and commentators have accentuated this tendency. Nevertheless, stark periodisation is an artefact of 'long duration' studies that dissolves when attention is focused on briefer episodes. ${ }^{58}$ This is indeed what happens in Kuhn's book on black-body theory during the years 1894-1912. ${ }^{59}$ In that late work we see the arrival of quantum discontinuity in fundamental physics. This development suggests itself to anyone looking for an example of a Kuhnian paradigm-shift, as there could hardly be a more profound change in our background metaphysics. Kuhn's account is recognisably Kuhnian: scientists solve technical puzzles against a backdrop of metaphysical and methodological presuppositions, but these are not uniform. At no time do we see opposing ranks of scientists representing old and new paradigms drawn up in mutual incomprehension.

This historicism is an amalgam of elements found in Kuhn and some of his sources. It is not intended to supply a complete interpretation of Structure. Indeed, some of the elements of Structure mentioned here have plausible antecedents in anglophone philosophy. The meaning holism, for example, might be traced to Quine. Furthermore, Kuhn violates his own historicism by offering a general model of science, with ahistorical rules such as these:

Scientists will be reluctant to embrace [a new paradigm] unless convinced that two all-important conditions are being met. First, the new candidate must seem to resolve some outstanding and generally recognised problem that can be met in no other way. Second, the new paradigm must promise to preserve a relatively large part of the concrete problem-solving ability that has accrued to science through its predecessors. (1970 p. 169).

However, an inconsistency between Kuhn's historicist methods and his ahistorical general model is not surprising given that Structure is a notoriously tangled book that stimulated more than it clarified (remember Masterman's twenty-one different senses of 'paradigm, ${ }^{60}$ ). Moreover, the absorption of historicism into Kuhn's thinking was partly unconscious, so we would not expect the result to be logically neat. To reiterate: Kuhn never pretended to understand the philosophical background of his European heroes. His remarks about 
periodisation (quoted above) suggest that he knew that his approach to historiography would influence the resulting conception of science and its history. However, his lack of an explicit philosophy of historiography prevented him from developing that thought beyond a few defensive comments. Ironically, Kuhn instantiated one of his own theses: he copied his mentors' approach without grasping its principles. It is not patronising to say this: Kuhn said as much himself in the references to the 'opaque' European tradition.

The merit of this reading is to explain why the ensuing debate generated so much more heat than light. Why did Kuhn's book cause such a storm? It was not just because it took issue with the prevailing views about science-philosophers take issue with orthodoxies all the time. Part of the answer lies in the difficulty philosophers had in getting a logical grip on it. Without the background given here, the relativism, 'irrationalism' and incommensurability in Structure seem like partly-historical-partly-philosophical claims. This apparent dual status made them maddeningly impervious to criticism. Philosophical counter-argument seemed to be met with further historical detail, while historical counter-instances seemed to be rebutted with philosophical critique. Structure (and the storm that broke over it) makes more sense if we see its model of science as in part a condensation of the a priori methodology of a certain school of history. The familiar claims, that science is directed in part by extra-scientific influences; that the history of science is divided by revolutionary breaks into periods that cannot be easily compared; that there is no ahistorical standard of rationality by which past episodes may be judged; and that science cannot be shown to be heading towards the Truth-these now appear as methodological commitments rather than historico-philosophical theses. Kuhn made waves by dropping a historicist stone into a scientistic pond. 


\section{References}

Amunàtegui, G.I. (2002). E. Husserl et A. Koyré: un point de rencontre. Revue de Questions Scientifiques 173(1) 73-78.

Ashplant, T.G. \& Wilson, A. (1988). Whig-History and Present-Centred History. The Historical Journal 31 (1), 1-16.

Bird, A. (2002) Thomas Kuhn. Chesham: Acumen Publishing Limited.

Butterfield, H. (1931). The Whig Interpretation of History. London: Bell (reprinted by Penguin, 1973).

Butterfield, H. (1949). The Origins of Modern Science. London: Bell ( $2^{\text {nd }}$ edition 1957).

Butterfield, H. (1955). Man on his past. Cambridge: Cambridge University Press.

Butterfield, H. (1964). The History of Historiography. In Fernand, B. (ed.). Mélanges Alexandre Koyré: II l'aventure de l'esprit. Paris, Harmann.

Cohen, I.B. (1987). Alexandre Koyré in America: some personal reminiscences. In Redondi, P. (ed.). Science: The Renaissance of a History (pp. 55-70). London, Paris, New York \& Melbourne: Harwood Academic Publishers.

Collingwood, R.G. (1994). The Idea of History (revised edition). Oxford: Oxford University Press.

Cowling, M. (1979). Herbert Butterfield 1900-1979. Proceedings of the British Academy, $\underline{\mathrm{LXV}}$, 595-609.

Elton, G.R. (1969). The Practice of History. London: Fontana.

Elton, G.R. (1984). Herbert Butterfield and the study of history. The Historical Journal XXVII, 729-743.

Elkana, Y. (1987). Alexandre Koyré: Between the history of ideas and the sociology of disembodied knowledge. In Redondi, P. (ed.), Science: The Renaissance of a History (pp. 115-148). London, Paris, New York \& Melbourne: Harwood Academic Publishers.

Fuller, S. (2000). Thomas Kuhn: a Philosophical History for Our Times. Chicago: University of Chicago Press.

Hacking, I. (1993). 'Working in a New World: the Taxonomic solution' in P. Horwich (ed.), World Changes: Thomas Kuhn and the nature of science (pp. 275-310). Cambridge, Mass: MIT Press.

Hall, A.R. (1983). On Whiggism. History of Science XXI, 45-59.

Hoyningen-Huene, P. (1993). Reconstructing Scientific Revolutions: Thomas S. Kuhn's Philosophy of Science. Chicago: University of Chicago Press.

Jorland, G. (1981). La science dans la philosophie: Les recherches épistémologiques d'Alexandre Koyré. Éditions Gallimard.

Koyré, A. (1943). Galileo and Plato. Journal of the History of Ideas vol. IV no. 4, 400-428.

Koyré, A. (1946). Philosophie de l'histoire. Europe, September, 108-117.

Koyré, A. (1953). An Experiment in Measurement. Proceedings of the American Philosophical Society vol. 97 no. 2 (April).

Koyré, A. (1961). Études d'Histoire de la Pensée Philosophique. Paris, Armand Colin.

Koyré, A. (1973). Études d'Histoire de la Pensée Scientifique. Paris, Éditions Gallimard, (original: Presses Universitaires de France, 1966).

Kuhn, T.S. (1957). The Copernican Revolution: Planetary Astronomy in the Development of Western Thought. Cambridge: Harvard University Press.

Kuhn, T.S. (1970). The Structure of Scientific Revolutions (second edition). Chicago: University of Chicago Press, (first edition 1962).

Kuhn, T.S. (1970a). Alexandre Koyré and the History of Science: on an Intellectual 
Revolution. Encounter 34, 67-69

Kuhn, T.S. (1970b). Notes on Lakatos. Boston Studies in the Philosophy of Science VIII, 137-46.

Kuhn, T.S. (1977). The Essential Tension: Selected Studies in Scientific Tradition and Change. Chicago: University of Chicago Press.

Kuhn, T.S. (1978). Black-Body Theory and the Quantum Discontinuity 1894-1912. Oxford: Clarendon Press.

Kuhn, T.S. (2000). The Road Since Structure. Conant \& Haugeland (eds). London: University of Chicago Press.

Masterman, M. (1970). The Nature of a Paradigm. In Lakatos and Musgrave (eds.). Criticism and the Growth of Knowledge (pp. 58-89). Cambridge University Press.

Meyerson, E. (1930). Identity and Reality. London: George Allen \& Unwin Ltd.. Tr. Loewenberg. First published in French, 1908.

Olesen, S.G. (1994). L'héritage Husserlien chez Koyré et Bachelard. Danish Yearbook of Philosophy 29, 7-43.

Redondi, P. (ed.). (1986). De la mystique à la science. Cours, conférences et documents1922-1962. Paris: Éditions de l'école des hautes études en sciences sociales.

Redondi, P. (ed.). (1987). Science: The Renaissance of a History. London, Paris, New York \& Melbourne: Harwood Academic Publishers.

Spiegelberg (1960). The Phenomenological Movement vol. 1. Martinus Nijhoff.

Worrall J. (2000). Kuhn, Bayes and Theory-Choice. In Nola \& Sankey (eds), After Popper, Kuhn and Feyerabend (pp. 125-151). Dordrecht: Kluwer Academic Publishers.

Zambelli, P. (1995) Alexandre Koyré versus Lucien Lévy-Bruhl: From Collective Representations to Paradigms of Scientific Thought. Science in Context, 8(3), 531555.

${ }^{1}$ Versions of this paper were read at the universities of Hertfordshire and Hannover. I am grateful to the participants in those seminars and to various individuals, including Steve Fuller, D. G. Shaw, Richard Ashcroft and Cristina Chimisso who provided extensive and useful criticism.

${ }^{2}$ This move is not confined to later editions of The Structure of Scientific Revolutions. Here is the opening of a lecture delivered in 1968: "I stand before you as a practicing historian of science. Most of my students mean to be historians, not philosophers. I am a member of the American Historical, not the American Philosophical, Association." (1977 p. 3). Mark the sequel though, "But for almost ten years after I first encountered philosophy as a college freshman, it was my primary avocational interest..." More recently, and with different rhetorical intent, Kuhn describes himself principally as a philosopher (2000 p. 106).

${ }^{3}$ Kuhn 1970 p. 206; emphasis added.

${ }^{4}$ Kuhn 1970 p. 208; emphasis added.

${ }^{5}$ See 1970 chapter X pp. 111-135.

61977 pp. xi-xii.

${ }^{7}$ Hacking makes a version of this point (1993 p. 276). See also Collingwood's thesis that a historian literally re-enacts the thoughts of historical actors (1994 pp. 217ff). Koyré discusses periodisation in 'La pensée moderne' (1966 pp. 16-23).

${ }^{8}$ Kuhn 1977 p. xv.

${ }^{9}$ Kuhn 1977 p. xv.

${ }^{10}$ At least, he did so in the crucial period when he wrote Structure. For a partial recantation, see 'The Trouble with the Historical Philosophy of Science' (2000 pp. 105-120).

${ }^{11}$ As Cohen (1987) explains, the division between the history of science and the philosophy 
of science was more institutionalised in the USA than in France: "American philosophers, generally steeped in some variety of analytical philosophy, have not considered history to be of any primary significance... many historians of science in American universities have become members of history departments. Their training requires study in history rather than philosophy and they have professional links with associations of historians rather than philosophers. In Continental European universities, historians of science tend to come from and be linked to philosophy..." (pp. 64-65). Cohen ought to have restricted his remarks to philosophers of science, and cast them in the past tense. Philosophy in the USA is diverse, and by 1987 philosophers of science had discovered history.

${ }^{12}$ Kuhn 1977 pp. 108-109.

13 "No one in recent years has done so much to clarify and deepen my consideration of philosophical problems as my Princeton colleague C.G. Hempel” (1977 p. 12). Kuhn only met Hempel in the mid 'sixties. His formal philosophical education was confined to some undergraduate courses (I am grateful to Paul Hoyningen-Huene on this point).

14 “tellement infectée d'historicisme qu'elle ne conçoit pas qu'il puisse y avoir d'elle-même une autre connaissance que la connaissance historique, époque qui n'admet pas qu'elle puisse se comprendre et s'expliquer à elle-même si ce n'est à travers et en fonction de son passé, son histoire." Quoted in Jorland (1981 p. 72). See also Koyré (1966 p. 17) "le style de notre époque, éperdument théorique, éperdument pratique, mais aussi éperdument historique...". ${ }^{15}$ See Hoyningen-Huene (1993 p. 18) for the role of Kuhn's heroes.

${ }^{16}$ Butterfield 1964, in which he observed that in the nineteenth century, historical thought "insinuated itself into innumerable branches of study, as though questions on any subject were to be answered by the method of studying antecedents" (p. 63).

${ }^{17} 1949$ p. 5 . See also p. 39 , "though dissection was being practised to an increasing degree it produced little result - men only observed the things which the ancient writer Galen had taught them to look for." Cf. Kuhn 1970a p. 68. See Kuhn (1977 pp. xiii, 35, 46, 131-2) for his assessment of Butterfield's contribution.

${ }^{18}$ Kuhn 1977 p. 5.

${ }^{19}$ Kuhn 1977 p. 17.

${ }^{20}$ Kuhn 1977 pp. 17-18.

${ }^{21}$ Butterfield 1931 p. 56.

${ }^{22}$ Butterfield offers Carlyle as an example.

${ }^{23}$ Butterfield 1931 p. 58

${ }^{24}$ Cowling (1979), Hall (1983), Elton (1984) and Ashplant \& Wilson (1988). They all observe that Butterfield sometimes failed to meet his own standards, as must any teacher of virtue who is also an active human being. More interesting is Hall's argument that (as a good historian) Butterfield found himself writing progressivist history of science because science has in fact progressed. However, this does not require us to regard such progress as inevitable nor to abandon the project of dealing with the past in its own terms. Hall writes "oscillations of interpretation take place about an ascending curve of information... and in some cases of mathematical sophistication..." (p. 58). But information and mathematical formalisms may be common to several Kuhnian disciplinary matrices.

${ }^{25} 1970$ a p. 67.

26 " C' 'est au contact direct des sources, dans le travail concret de leur maniement et de leur critique que s'affine le sense historique de l'historien..." (1946 p. 114).

${ }^{27}$ Jorland 1981 p. 79 . See also 'Traduttore-Traditore' in Koyré 1966 pp. 272-4.

${ }^{28} 1970$ a p. 68. 
${ }^{29}$ Jorland 1981 p. 85; Koyré 1966 p. 14.

${ }^{30}$ Schuhmann (1987) p. 158. Schuhmann argues that Reinach's influence on the Göttingen students, including Koyré, was much greater than that of Husserl, and that Reinach's encyclopedic knowledge of the history of philosophy makes him a more likely influence on Koyré than Husserl. However, Reinach was killed by enemy action in 1917, whereas Koyré and Husserl had close personal and professional relations until Husserl's death in 1938.

Schuhmann's argument requires Koyré to conflate Reinach and Husserl in his letter to Spiegelberg. In any case, all the present argument requires is that Koyré imbibed some phenomenology at an early age. Olesen (1994) and Amunàtegui (2002) find similarities of tone and content in Husserl's Crisis and Koyré's work on Newton.

${ }^{31}$ Jorland 1981 p. 28 . Original in English. Partially reproduced in Spiegelberg (1960 p. 225).

${ }^{32}$ See 1966 pp. 16-23.

${ }^{33}$ This does not require the further claim that a change of paradigm requires a Gestalt switch.

${ }^{34}$ Olensen (1994 p. 15) draws attention to the following passage: “...il faut se méfier des appréciations trop hâtives - ce quit était admirable hier peut ne plus l'être aujourd'hui, et, inversement, ce qui hier était ridicule peut aujourd'hui ne pas l'être du tout. L'histoire nous montre bien des examples de ces corsi e ricorsi vraiment renversants et, si en aucun cas elle ne nous enseigne l' $\dot{\pi} \pi \circ \chi \eta$ [bracketing], elle nous enseigne sûrement la prudence." (Koyré 1961 p. 235). Indeed, bracketing does not follow from the historical record as a corollary. Rather, the bracketing is implicit in the writing of the record.

35 "Un incroyant peut-il comprendre, c'est-à-dire revivre en lui-même, les attitudes de la foi?... Pourrait-il être un historien?" (Koyré 1966 p. 111). See also Jorland 1981 p. 76 and Collingwood 1994.

${ }^{36}$ Koyré's Platonist leanings explain why he could not unify the internal history of science with its social history. For him the history of science and philosophy (or better, the history of thought) is the history of objective ideas for which people are vehicles. Kuhn, thinking that Koyré avoided social history as a matter of talent and taste, was surprised when Koyré congratulated him on bringing the internal and external histories of science together (Kuhn 2000 p. 286). This story makes more sense if Koyré's own Platonism prevented him from attempting a unification that he saw to be otherwise desirable.

${ }^{37}$ Crisis and The Origin of Geometry are obvious exceptions.

${ }^{38}$ Several authors comment on the connection between Koyré and the sociologist Lucien Lévy-Bruhl (Elkana 1987, Bird 2000 pp. 17-19, Zambelli 1995). I am persuaded by Zambelli's argument that Koyré read Lévy-Bruhl's work on collective representations and attitude mentale as a group phenomenology. Redondi (1986 p. xi) argues that Koyré and Lévy-Bruhl share a common ancestor in Paul Tannery, who in his work on Galileo appealed to the 'state of the contemporary mind' ("l'état d'esprit contemporain"). Of course Koyré read Tannery, but Redondi offers no direct textual connection. Kuhn mentions "the universally venerated" Tannery briefly (1977 p. 109). Of the three recent book-length studies of Kuhn, Bird makes no mention of Koyré, while Fuller and Hoyningen-Huene make no mention of Lévy-Bruhl.

${ }^{39}$ Hoyningen-Huene mentions "the historiography of Koyré and his school, which in turn hearkens back to neo-Kantianism" (p. xviii). There are no clear neo-Kantian traces in Koyré's work (except insofar as Brunschvicg counts as a neo-Kantian). Oddly, HoyningenHuene uses Kant to discuss the phenomenological aspect of Kuhn's work and neglects Husserl entirely except to borrow his vocabulary on a couple of occasions. This, even though the route from Kuhn to Husserl is far better established than that from Kuhn to the neo- 
Kantian movement. Hoyningen-Huene may have been misled by Kuhn himself here, who (as we have seen) regarded his European mentors as 'post-Kantian' thinkers. Post-Kantian is one thing. Neo-Kantian is another.

${ }^{40}$ Jorland 1981 p. 99. Kuhn concurs at 1970a p. 68.

${ }^{41}$ See Koyré 1953.

${ }^{42}$ Koyré 1943.

${ }^{43}$ It is thus ironic that both Koyré's own papers $(1961,1966)$ and the anthologies in celebration of his seventieth birthday divide the history of science and the history of philosophy into separate volumes.

44 “'On ne comprend pas véritablement l'œuvre de l'astronome, ni celle du mathématicien, si on ne la voit pénétrée de la pensée du philosophe et du théologien." (1966 p. 12). See also ibid. p. 392ff, and "Les faits littéraires ne sont nullement indépendents des faits économiques, des faits politiques..." (1966 p. 110). Jorland 1981 pp. 42-52.

45 Jorland 1981 pp. $96-97$.

${ }^{46} 1977$ pp. xi-xii.

47 "In Kuhn's cosy world, everyone is rational-revolutionary and reactionary alike." (Worrall, 2000 p. 126). 'Cosy' suggests that Kuhn wrote up dead scientists as rational out of naivety rather than following a methodological principle.

48 "La science ne marche pas de vérités définitivement acquises à d'autres découvertes définitives. La science est progrès, acheminement vers le vrai; sa valeur est dans son dynamisme qui ne laisse rien immobile et sur place; et l'étude de cet effort de la pensée humaine dans sa lutte pour la connaissance du réel peut seul nous éclarer sur le sens même de son dynamisme, sur le sens des notions fondamentales qu'elle emploie; et la vision du passé nous aidera à définir des normes applicables à l'avenir" (quoted in Jorland 1981 p. 89). See also Koyré 1966, p. 399.

491970 p. 206. See the discussion at Jorland 1981 p. 93.

501977 p. 16.

${ }^{51}$ Butterfield 1931 p. 54

52 "C'est par le changement seulement que se révèle à nous la réalité du temps. L'histoire... n'existe que là où il y a changements.” (1966 p. 116). “...dans mes travaux, je me suis surtout attaché à montrer, non pas le fond identique de la pensée humaine, mais les différences de ses structures aux diverses époques de l'histoire." (Redondi (ed.) 1986 p. 139). ${ }^{53}$ See Jorland 1981 p. $90 \mathrm{ff}$.

${ }^{54}$ Kuhn 1970 p. 9

${ }^{55}$ Kuhn 1977 p. 18. For more of the same, see (e.g.) Elton: "Sociologists establish 'models' which they test by supposedly empirical evidence. To an historian this seems a very dangerous procedure: far too often the model seems to dictate the selection of facts used to confirm it." (1969 p. 55n25).

${ }^{56}$ Historicism in this sense is thus the very opposite of the view that Popper criticised in The Poverty of Historicism (i.e. that prediction is possible given the identification of a suitable essence such as 'the Germans' or 'the proletariat').

${ }^{57}$ Cf. Koyré 'L'histoire se divise en histoires. Une division qui, sans doute, n'est pas arbitraire, du moins pas entièrement arbitraire, mais qui, tout de même, reste sujette à caution; en effet, aucun découpage donné ne s'impose. On sent bien que l'on pourrait découper autrement." (1966 p. 110).

${ }^{58}$ I owe this thought to Raz Chen-Morris of the University of Tel Aviv. See also Koyré 1966 pp. 16-17. 
${ }^{59}$ Kuhn 1978. Kuhn's publications from 1951 to 1961 are almost entirely in the history of science. Apart from the black-body book his historical work dried up almost entirely after the publication of Structure, as he wrestled in print with the issues it raised.

${ }^{60}$ Masterman 1970 p. 61. 